\title{
INTERNAL FACTORS BEHIND THE EMERGENCE OF THE LAW OF TREASON IN THE GRAND DUCHY OF LITHUANIA IN THE MID-FOURTEENTH TO MID-FIFTEENTH CENTURIES
}

\author{
Andrej Ryčkov
}

\begin{abstract}
The article presents an analysis of internal factors behind the emergence of treason as a crime in the Grand Duchy of Lithuania in the mid-14th to mid-15th centuries. The research showed that the main social group in which this crime started to form in the early to mid-15th centuries were the grand duke's adversaries and foes (Latin: adversarius, inimicus; Ruthenian: недруг, неприятель, враг; German: fynd). The appearance of terms for treason within the context of precisely this social group is evidence of the intensifying links between state structures, whereby closer bonds were established between the ruler and his officials/friends, primarily within the institutional milieu of the ruler's court and the system of public offices. In this particular context, going beyond the boundaries of loyalty and allegiance was no longer understood just as a demonstration of hostility, but as the crime of treason.
\end{abstract}

Research on the topic of treason as a crime has gained pace over the last decade. Three collections of articles present this problem, offering a broad introduction to treason in the Middle and Early Modern ages. ${ }^{1}$ The geography of this research spans from South America to Asia Minor, while the research topics range from analyses of specific cases of treason to the treatment of treason as a punishable crime, or trying to establish the concept of 'going astray' morally. Kiril Levinson, a member of the Одиссей journal's editorial

1 'Вірність' - 'зрада' в уявленнях і практиках середньовіччя $і$ раннього нового часу. Соціум. альманах соціальної історії (Київ, 2006); La trahison au Moyen Âge: de la monstruosité au crime politique, Ve-XVe siècle, sous dir. M. Billoré et M. Soria (Rennes, 2009); Одиссей. Человек в истории. Предательство: опыт исторического анализа (2012); this issue has become a topic of research not just among historians, but sociologists as well. It has been explored in more detail in sociology by Sebastien Scher 'Sociologie de la trahison', Cahiers Internationaux de Sociologie, 2007/2 (no. 123), pp. 313-323. 
board, when speaking about the articles presented in the collection, draws attention to the fact that so far, no single uniform theory or methodological approach to research on treason has been established. ${ }^{2}$

The crime of treason against the ruler in the context of research on the Grand Duchy of Lithuania (GDL) has also caught the attention of scholars, through rarely as an actual object of research. Works have been written about the crime of treason in the GDL, especially in the legal discourse, where the main source for learning about this crime were the norms outlined in the Statutes of Lithuania, ${ }^{3}$ as well as the analysis of the evolution this crime in the states of Poland ${ }^{4}$ and Russia. ${ }^{5}$ Karol Łopatecki ${ }^{6}$ attempted to conduct one of the most comprehensive studies on acts of treason against the ruler in the GDL. According to this scholar, the crime formed in the GDL in the early 16 th century as a result of the military conflict between the Muscovy and Lithuania. ${ }^{7}$ By raising this hypothesis, Łopatecki tried

${ }^{2}$ К. Левинсон, 'Предисловие', Одиссей. Человек в истории, p. 9, footnote 3.

${ }^{3}$ I shall not list all the studies that have examined the norms in the Statutes of Lithuania, but limit myself to just some of the more significant ones: K. Koranyi, 'O niektórych postanowieniach karnych Statutu litewskiego z r. 1529 (Studium prawno-porównawcze)', Księga pomiantkowa ku uczczeniu czterechsetnej rocznicy wydania pierwszego Statutu Litewskiego, ed. S. Ehrenkreutz (Wilno, 1935), pp. 123-157; А. Хорошкевич, “«Здрада» Статута Великого княжества Литовского 1588 г., «измена» Соборного Уложения 1649 г. и демографическая политика восточноевропейских государвств конца XVI - начала XVII вв.', 1588 metu Trečiasis Lietuvos Statutas, Respublikinès mokslinès konferencijos, skirtos Trečiojo Statuto 400 metinèms pažymèti, medžiaga (Vilnius, 1989), pp. 50-62; 'Pirmojo Lietuvos Statuto komentarai', Pirmasis Lietuvos Statutas (1529 m.), I. Valikonytė, S. Lazutka, E. Gudavičius (Vilnius, 2001), pp. 267-268; 'Комментарии разделов Первого Литовского Статута', Первый Литовский Статут (1529 г.), подготовили С. Лазутка, И. Валиконите, Э. Гудавичюс (Вильнюс, 2004), pp. 325-326, 334.

${ }^{4}$ A. Lityński, Przestęstwa polityczne $w$ polskim prawie karnym XVI-XVIII wieku (Katowice, 1976); M. Dyjakowska, Crimen laesae maiestatis. Studium nad wplywami prawa rzymskiego $w$ dawnej Polsce (Lublin, 2010).

${ }^{5}$ O. Backus, 'Treason as a Concept and Defections from Moscow to Lithuania in the Sixteenth Century', Forschungen zur Osteuropäischen Geschichte, 15 (1970), pp. 119-144; A. Rustemeyer, 'Princes, parents et seigneurs. Loyautés et crime contre le souverain en Europe centrale ou occidentale et en Moscovie XIVe - XVIIe siècle', Cahiers du monde russe, 46 (2005), pp. 251-264; К. Ерусалимский, 'Рождение государственной измены: Россия и Польско-Литовское государство конца XV-XVI вв.', Одиссей. Человек в истории, pp. 154-187.

${ }^{6} \mathrm{~K}$. Łopatecki, Organizacja, prawo i dyscyplina w polskim i litewskim pospolitym ruszeniu (do połowy XVII wieku) (Białystok, 2013), pp. 247-271.

${ }^{7}$ K. Lopatecki, Organizacja, pp. 248-249. 
to reconstruct the phenomenon of treason firstly as a war crime, and thus 'lost' some of its components, for example, forgery of the ruler's writs and seals. Stephen C. Rowell proposed a completely different trajectory for this research. He researched the crime of treason during the epoch of Grand Duke Casimir, 1440-1481, from 'below', that is, by analysing how the nobility, especially the magnates, viewed the crime. ${ }^{8}$ This approach opened up a new direction of research, yet the approach taken towards treason was based on the later epistolary of Albertas Goštautas from the middle of the 1520s.

Summarising the historiography, we can state that the research on treason in the GDL is based primarily on the legal ideas of the 16th century, and that 16th-century realities are applied to earlier epochs as well. We have already noticed that terms referring to treason in the GDL appeared in sources in the mid-15th century, while the first legal regulation of the crime occurred in the $1440 \mathrm{~s} .{ }^{9}$ It would be misleading to believe that the crime of treason against the ruler in the first half of the 15th century was identical to the same crime one hundred years later, in the first half of the 16th century. It was not just an enormous change in social structures that took place in society in this period, but also a transformation of state structures. The archaic method of state rule based on personal links was replaced by an institutional model for state rule. For the purposes of this article, we shall settle on an examination of the internal reasons for acts of treason against the ruler in the GDL. ${ }^{10}$ First of all, we shall identify the milieu that facilitated the formation of the crime. Later, based on an analysis of the text of the peace treaty between the grand dukes of Lithuania and the palatines of Moldova, we shall present the beginning of the legal codification of treason.

The development of the concept of treason in the early to middle of the 15th century should be associated with the transformation of the system of rule. As the study by Rimvydas Petrauskas illustrated, this

${ }^{8}$ S.C. Rowell, 'Išdavystè ar paprasti nesutarimai? Kazimieras Jogailaitis ir Lietuvos diduomenè 1440-1481 metais', Lietuvos valstybe XII-XVIII a., ed. Z. Kiaupa, J. Sarcevičiené (Vilnius, 1997), pp. 45-74; S. C. Rowell, 'Bears and Traitors, or: Political Tensions in the Grand Duchy, ca. 1440-1481', Lithuanian Historical Studies, 2 (1997), pp. 28-55.

${ }^{9}$ A. Ryčkov, 'Valdovo išdavystès kaip nusikaltimo sampratos ištakos Lietuvoje', Lietuvos istorijos metraštis. 2013 metai (2014), pp. 50, 59-62.

${ }^{10}$ For more on the external reasons for the emergence of this crime in the GDL, see: A. Ryčkov, 'Valdovo išdavystès', pp. 49-63. 
transformation was not evolutionary, but had a distinct revolutionary aspect, whereby individual rulers managed to 'unite the aristocracy, concentrate the most critical forms of leverage for maintaining power in their hands, and to initiate changes to the system of rule'. ${ }^{11}$ On the other hand, this revolutionary process did not cover all spheres of state life, so some were 'destroyed' gradually, thus changing the established 'past'. ${ }^{12}$ We could believe that the concept of treason as a crime was only taking its first steps in the consciousness of Lithuania's political society until the middle of the 15 th century. The concept of the crime was in a period of transition at this time, when Western criminal terminology started being applied, while the earlier, everyday attributes of political practice only slowly made way for new practices and institutions. ${ }^{13}$

To rephrase Simon Hirsch Cuttler, one of the most authoritative researchers of treason against rulers in the Middle Ages, treason was the greatest political crime par excellence. It was considered a greater crime than betrayal, as it was directed against the highest state public authority, whose main representative was the ruler himself. ${ }^{14}$ Thus, it is important to note that the appearance of terminology for

${ }^{11}$ R. Petrauskas, 'Ankstyvosios valstybinès struktūros Lietuvoje XIII amžiuje XV amžiaus pradžioje’, Lietuvos istorijos studijos, 16 (2005), p. 29.

${ }^{12}$ For more on the early concept and its change in the GDL, see: M. Кром, '«Старина» как категория средневекового менталитета (по материалам Великого княжества Литовского XIV - начала XVII вв.)', Mediaevalia ucrainica. Ментальність та історія ідей, 3 (Киів, 1994), pp. 68-85; А. Блануца, Д. Ващук, 'Інститут «старини» й «новини» в правах та економічних джерелах Великого князівства Литовського (друга половина XV-XVI ст.)', Украӥнський історичний журнал, 467/2, (2006), рр. 11-23; Д. Ващук, „Абыхмо деръжали ихъ пюдль права ихъ земъли' (Населення Київщиии та Волині ї великокнязївська влада в XV-XVI cm.) (Київ, 2009), pp. 195-227; А. Груша, 'Улада непарушнасці і памяці: 'старина' і яе трансфармацыя ў XV - першай трэці XVI ст.', Соціум. Альманах сочіальної історії, 10 (2013), pp. 216-244.

${ }^{13}$ For example, the formation of institutions such as the ruler's court and the Council of Lords. See: R. Petrauskas, 'Didžiojo kunigaikščio institucinio dvaro susiformavimas Lietuvoje (XIV a. pabaigoje - XV a. viduryje)', Lietuvos istorijos metraštis. 2005 metai (2006), pp. 5-36; idem, 'Nuo Vytauto iki Aleksandro Jogailaičio: didžiojo Lietuvos kunigaikščio dvaro tęstinumo problema', Lietuvos didysis kunigaikštis Aleksandras ir jo epocha, ed. D. Steponavičienè, (Vilnius, 2007), pp. 47-55; L. Korczak, Litewska rada wielkoksiązęca w XV wieku (Kraków, 1998); L. Korczak, Monarcha i poddani. System władzy w Wielkim Księstwie Litewskim $w$ okresie wczesnojagiellońskim (Kraków, 2008), pp. 31-43.

${ }^{14}$ S.H. Cuttler, The Law of Treason and the Treason Trials in the Later Medieval France (Cambridge, et al., 2002), p. 1. 
the crime of treason could be held as an indicator of the expression of Lithuanian state structures. This does not mean at all that state structures did not exist before the appearance of these terms in sources. On the contrary, the appearance of such terms in sources is evidence of the qualitative transformation of these structures.

\section{The adversaries and foes of the grand dukes}

The main group based on which the concept of treason, as a crime, formed was the category of the ruler's adversaries and foes (Latin: adversarius, inimicus; Ruthenian: недруг, неприятель, враг; German: fynd). It is difficult to unequivocally state who and in what instances could be attributed to this category. These multi-lingual terms can cause confusion in themselves. The semantic field of Latin terms for this category is narrower than the Ruthenian or German equivalents. The terms from the latter languages describe not just foes/adversaries or opponents, but enemies as well. ${ }^{15}$ In Latin sources, enemies were usually identified by the term hostis. Another meaning of this word was foreigner, which explains why it was usually used to identify 'external enemies'. ${ }^{16}$ For example, the privilege of Jogaila of 1387 distinguished between the grand duke's enemies and adversaries (hostes et adversarios nostros). ${ }^{17}$ On the other hand, the imprecise use of terminology in multi-lingual sources allows us to view the category of the grand duke's adversaries and foes as more of an 'etic' than an 'emic' concept. ${ }^{18}$

15 The term враг in sources from the period being discussed is usually found in religious texts containing religious content. 'Ворогъ, Врагъ', Гістарычны слоўнік беларускай мовы, 4 (Мінск, 1984), р. 187, 250; 'Недругъ, Неприятель, нериатель, нериетель, нерыятель', Гістарычны слоўнік беларускай мовы, 20 (Мінск, 2001), pp. 93, 270-271.

${ }^{16}$ For more on the earliest semantic meaning of the term hostis: Э. Бенвенист, Словарь индоевропейских сочиальных терминов. I. Хозяйство, семья, общество. II: Власть, право, религия, перевод с французкого Н.Н. Казанского, Б.П. Нарумова, С.Г. Проскурина, О.М. Савелевой, Н.Л. Сухачева (Москва, 1995), pp. 77-79.

${ }^{17}$ Lietuvos Metrika (1387-1546), 25-oji Užrašymu knyga, compiled by D. Antanavičius, A. Baliulis (Vilnius, 1998), no. 1, p. 36.

${ }^{18}$ In cultural anthropology methodology, 'emic' concepts are used by members of the culture or society that are being studied by the researcher, while 'etic' concepts are those that are created by the researcher who is studying a particular culture or society 'from afar'. See Z. Norkus, Nepasiskelbusioji imperija. Lietuvos Didžioji Kunigaikštija lyginamosios istorinès imperijų sociologijos požiūriu (Vilnius, 2009), p. 78. 
There was no one single category of enemies during the period being discussed. An exceptional role in this category must have gone to members of the reigning dynasty, who could have expressed claims to the grand duke's throne. ${ }^{19}$ For example, in the treaty of 1386 between Yuri Sviatoslavich, the Prince of Smolensk, and Jogaila and Skirgaila, his vicegerent in Lithuania, the status of the Gediminids was mentioned separately when defining their union against common foes:

whomever the king and his brother Grand Duke Skirgaila shall not keep peace with, so too shall I not keep peace with them, even though with his other brothers [and cousins] he might not keep peace, I too shall not keep peace with them either, nor with Andrei of Polotsk and the Polotskians, nor shall they send to me any legations. ${ }^{20}$

Relations between enemies of the ruler, the Gediminid dukes, were defined along similar lines in the 1433 Treaty of Łęczyca, ${ }^{21}$ the 1435 Treaty of Brest, ${ }^{22}$ and the 1449 treaty with Muscovy. ${ }^{23}$ The other treaties from this period banned the partner country from taking and holding captive enemies of another state, or allowing an enemy army to cross through its territory. ${ }^{24}$ Apart from members

${ }^{19}$ For more, see: Lietuvos istorija, t. 3: D. Baronas, A. Dubonis, R. Petrauskas, XIII a. - 1385 m.: valstybès iškilimas tarp Rytu ir Vakarų (Vilnius, 2011), pp. 354-358.

${ }^{20}$ С кимь король не миренъ. и брать его книзь велики скиригкаило и с тымь и азъ не миренъ хота бы с ыною братьею своею не миренъ и с тыми миру не держати ми и со Фндреемъ полочкимъ и с полочаны миру не держати ми ани сылатисл. Грамоти XIV cm. Памятки украіньскоі мови, упорядкування, вступна стаття, коментарі і словники-покажчики М. Пещак (Киів, 1974), по. 37, р. 70.

${ }^{21}$ Die Staatsverträge des Deutschen Ordens in Preußen im 15. Jahrhundert, Bd. 1, (1398-1437) hrsg. von E. Weise (Königsberg, 1939), no. 176, p. 192.

22 Staatsverträge, Bd. 1, no. 182, p. 201.

${ }^{23}$ Lietuvos Metrika (1427-1506), 5-oji Užrašymu knyga (henceforth LM 5), compiled by A. Baliulis, A. Dubonis, D. Antanavičius (Vilnius, 2012), no. 541, p. 358.

${ }^{24}$ The 1397 peace treaty between Vytautas and the Teutonic Order. Codex epistolaris Vitoldi magni ducis Lithuaniae 1376-1430. Monumenta medii aevi historica res gestas Poloniae illustrantia (henceforth CEV), collectus opera A. Prochaska (Cracoviae, 1882), no. 140, p. 44; 1398 Treaty of Salynas. Staatsverträge, Bd. 1, no. 2, p. 12; Liv-, esth- und curländisches Urkendenbuch, Bd. 4, hrsg. von F.G. Bunge (Reval, 1859), no. 1479, col. 226; 1402 treaty between Švitrigaila and the Teutonic Order. Ibidem, no. 1603, col. 413; A. Kotzebue (appendices), Switrigail. Ein Beytrag zu den Geschichten von Litthauen, Rusland, Polen und Preussen (Leipzig, 1820), no. 9, p. 168; 1404 Peace of Raciąż. Staatsverträge, Bd. 1, no. 23, p. 33; 1404 treaty between Vytautas and the Teutonic Order. CEV, no. 299, p. 105; 1422 Treaty of Melno. Staatsverträge, Bd. 1, no. 154, p. 162. 
of the ruling family, enemies in sources could be individuals, such as rulers of other states, other states (the Teutonic Order), or even neighbouring nations (the Tatars, Turks). A representative example could be the text of the treaty signed in 1395 by Jogaila and Stefan, the Palatine of Moldova, where the latter promised to provide assistance against all of Jogaila's enemies:

to help with all our might against all their [Jogaila's] enemies ${ }^{25}[\ldots]$ against the Hungarian king, the palatine of Bessarabia, the Turks, the Tatars, the Ruthenians, also [...] [against] the Teutonic Knights. ${ }^{26}$

In order to better understand and define the category of the ruler's adversaries and foes, we shall use the opposite form of social relations, the category of friendship. ${ }^{27}$ Rowell has already drawn attention to the importance of this form of social relations when he spoke about groups of the Lithuanian aristocracy that were just forming in the 1440s. ${ }^{28}$ However, Petrauskas has given the most thorough explanation of the friendship phenomenon in his analysis on how early state structures functioned in Lithuania. ${ }^{29}$ According to him, in archaic, poorly institutionalised societies, such as the Lithuanian state in the 13 th to early 15 th centuries, the category of friendship (Latin: атісі, Ruthenian: приятели, German: frunde) 'was an important form of social relations uniting society and entrenching a certain political organisation', ${ }^{30}$ which at the same time did not contravene but enhanced the bonds of subordination. Unlike hierarchial feudal relations, where the vassals of one senior did not necessarily form a united group, friendship was a network

${ }^{25}$ помогати подлуг всег нашег мочи противку встьхь ихъ неприятелии. Грамоти XIV cm., no. 66, p. 127.

${ }^{26}$ противку короля Оугорского, противку воеводы Басарабьского, противъ турковъ, противъ татаръ,противъ рус такеж [...] [против] нъмиомъ крыжевониемъ. Грамоти XIV cm., по. 66, р. 126.

${ }^{27}$ For more about the friendship category in the early Middle Ages: G. Althoff, Verwandte, Freunde und Getreue. Zum politischen Stellenwert der Gruppenbindungen im früheren Mittelalter (Darmstadt, 1990).

${ }^{28}$ Being related or married were also distinguished as separate categories. S.C. Rowell, 'Išdavystè ar paprasti nesutarimai?', p. 48.

${ }^{29}$ R. Petrauskas, 'Giminaičiai ir pavaldiniai: Lietuvos bajorų grupės XIV a. pabaigoje - XV a. I pusejje', Lietuva ir jos kaimynai. Nuo normanu iki Napoleono: prof. B. Dundulio atminimui, ed. I. Valikonyte (Vilnius, 2001), p. 112; idem, Lietuvos diduomenè XIV a. pabaigoje - XV a.: sudètis - struktūra - valdžia (Vilnius, 2003), pp. 174-176; idem, ‘Ankstyvosios valstybinès struktūros', pp. 24-26.

${ }^{30}$ R. Petrauskas, ‘Ankstyvosios valstybinès struktūros', p. 24. 
of horizontal links, joining individuals into a whole. ${ }^{31}$ Thus, state structures were created through the existence of double bonds, on the basis of subordination (legal) and friendship (moral). We know of the first friends/officials of the ruler from the times of Grand Duke Gediminas, who contributed to the creation of state structures. ${ }^{32}$ The ruler entrusted such officials/friends with a rather large degree of autonomy in implementing the grand duke's policies across the land. The lack of a culture of writing ${ }^{33}$ in the administrative process of state governance was partly compensated for by congresses held at the ruler's court that were held every so often, hunts, receptions, etc; ${ }^{34}$ also the fact that the grand duke's authority was expressed by his constant travelling. The importance of residential castles, where the ruler would stay for a long time, was more evident only during the reign of Grand Duke Vytautas in the early 15th century. ${ }^{35}$

Relations between the grand duke and his officials/friends had to be based on loyalty or expressions of allegiance, which to a certain extent were flexible. These limits were understood by contemporaries; however, their reconstruction does pose some difficulties for today's researchers. Tokhtamysh, the khan of the Ulus of Jochi, in a letter to Jogaila in 1393, complained: 'discord arose between us last year, our nephew Belek-Bulat and Khodja-Medin became our foe'. ${ }^{36}$ The

\section{p. 175.}

${ }^{31}$ R. Petrauskas, 'Giminaičiai ir pavaldiniai', p. 112; idem, Lietuvos diduomenè,

${ }^{32}$ For example, Dovydas, the castellanus of Hrodno. Chartularium Lithuaniae res gestas magni ducis Gedeminne illustrans, compiled by S.C. Rowell (Vilnius, 2003), p. 44.

${ }^{33}$ The institution of a permanent ruler's office was only established in the milieu of Grand Duke Vytautas. Before then, Lithuania's rulers relied on the services of the Orthodox and Catholic clergy. A. Dubonis, 'Raštininkas', Lietuvos Didžiosios Kunigaikštijos kultūra. Tyrinejiimai ir vaizdai, compiled by V. Ališauskas, L. Jovaiša, M. Paknys, R. Petrauskas, E. Raila (Vilnius, 2001), pp. 574-575.

${ }^{34}$ For more about everyday life at the court of Grand Duke Vytautas: R. Čapaitè, 'Lietuvos didžiojo kunigaikščio Vytauto kasdienybè pagal jo ir jo amžininkų korespondenciją, Alytaus miesto istorijos fragmentai, compiled by A. Jakunskienè (Alytus, 2001), pp. 18-27.

${ }^{35} \mathrm{~V}$. Volungevičius, Pilies šešèlyje. Teritorija, visuomenè ir valdžia Lietuvos Didžiojoje Kunigaikštysteje (Vilnius, 2015), pp. 82-83.

${ }^{36}$ Оу другомь пакъ льть стала межи нас замлтня нашь племеньник Бекбулатъ и Хожа Мединъ оучинился намъ ворогъ. Украӥньскі грамоти (XIV в. i перша половина $X V$ в.), 1, выд. В. Розов (Київ, 1928), nо. 26, p. 48. The term враг is often used in sources from the period discussed in texts containing religious content. 'Ворогъ, Врагъ', pp. 187, 250. 
specific actions that led to this discord and the rift between the rulers are not revealed in the letter, but we presume that they were known to both the addressee and the author of the letter.

We may presume that officials and friends who had stepped beyond the boundaries of loyalty and allegiance were also considered the grand duke's adversaries or foes. This boundary was associated somewhat with poor communication. For example, in his complaint against Jogaila and Skirgaila, Vytautas mentioned that his father Kęstutis and his uncle Algirdas had already decided which day both would have to arrive near Vilnius in order to overthrow Jaunutis for the grand duke's throne. However, due to reasons unknown that Vytautas did not outline in his complaint, 'Duke Algirdas could not arrive'. ${ }^{37}$ Later editions of the Lithuanian chronicles extrapolated on this episode, taking into account the communication difficulties: 'Grand Duke Algirdas was late in arriving in Vilnius from Vitebsk'. ${ }^{38}$ Kęstutis, it appears, left Trakai, captured his brother Jaunutis alone, and seated his elder brother Algirdas on the grand ducal throne as soon as he arrived. The fact that Algirdas was delayed did not prevent Kęstutis from attacking and occupying Vilnius himself. On the other hand, regardless of the fact that it was Kęstutis who took Jaunutis captive, he did not lay claim to the grand duke's throne, ${ }^{39}$ and, as per the agreement, gave it to Algirdas.

The boundaries of loyalty and allegiance were also associated with the undefined competencies of the ruler's officials/friends. In a letter dated 23 January (1397) to the Riga city council, Grand Duke Vytautas complained that his official Mangirdas, the Polotsk vicegerent, was not authorised to certify the peace and trade treaty between Duke Lengvenis and the city of Riga, the Livonian branch of the Teutonic Order, made on behalf of all of Lithuania. ${ }^{40}$ Vytautas

37 vnd herczog Algart der konde nicht komen. 'Dis ist Witoldes sache wedir Jagaln vnd Skargaln', Scriptores rerum prussicarum, Bd. 2, hrsg. von T. Hirsch, M. Töppen und dr. E. Strehlke (Leipzig, 1863), p. 712.

38 князь великии Олькгирд з Витебъска до Вилни борздо не неприспел. ‘Летопись Красинского', Полное собрание Русских летописей, 35, состав. и ред. Н. Улащик (Москва, 1980), p. 133.

${ }^{39}$ Perhaps he could have had priority, or referred to the 'first hand principle'? For more about the 'first hand principle' in the land management context: A. Dubonis, 'Žemèvalda', Lietuvos Didžiosios Kunigaikštijos kultūra. pp. 785-786.

${ }^{40}$ Another letter of similar content from Vytautas to the Rigans is dated 20 January (1398). I thank Sergey Polekhov for this reference. Полоикие грамоты. ХIII - начала XVI вв., 1, состав. А. Хорошкевич (Москва, 1977), по. 19, 21, pp. 67-68, 72 . 
claimed that not only had Duke Lengvenis entered into this treaty illegitimately, but that Mangirdas too had no grounds to authorise it, as without the ruler's approval he had no right 'to enter into a treaty in the name of Lithuania not even for half a day'. ${ }^{41} \mathrm{Un}-$ doubtedly, this position taken by the Lithuanian grand duke might have been dictated solely by the existing political circumstances, where Vytautas had to justify why the property of Rigan merchants was not legally protected in Lithuania. The selection of precisely this kind of argument would testify that the ruler's officials could sometimes overstep their undefined 'boundaries' of competency. Yet it is unlikely that this situation went beyond the boundaries of Mangirdas' and Grand Duke Vytautas' moral and legal relations. We have barely any data about Mangirdas' career highlights in the court of Grand Duke Vytautas; however, the careers of his sons illustrate that those relations must have remained very close indeed. ${ }^{42}$ Plus, there were more similar cases in the 14 th century. ${ }^{43}$

The interrelations between the grand duke and members of the ruling dynasty were qualitatively different to relations between members of the dynasty and other nobles. We could presume that the former bond was closer, which is why the boundaries of loyalty and allegiance were somewhat wider. Conflicts between Algirdas/ Kęstutis and Jaunutis, Kęstutis/Vytautas and Jogaila, Žygimantas Kęstutaitis and Švitrigaila, or Mykolas Žygimantaitis and Casimir, not to mention numerous other 'local' conflicts, demonstrate that representatives of the ruling dynasty were inclined to make peace and search for compromises, even though sometimes that compromise might have been 'reached' following the death of one of the conflicting parties. ${ }^{44}$ Let us consider a few of the more telling

${ }^{41}$ ein halbin tag frede uffzunemen ven der Littawen wegin. Ibid., no. 19, p. 68.

${ }^{42}$ Mangirdas died before 1410 . His son Alekna served as the deputy cup-bearer at Vytautas' court. His other son Petras served as the starosta of Podolia circa 1424-1426, and he was mentioned as being a marshal of the court in 1422/23. R. Petrauskas, Lietuvos diduomene, pp. 259-261.

${ }^{43}$ For example, the case of Liubartas and the Karijotaitis brothers. R. Petrauskas, 'Gediminaičiu pasaulis: tarptautinès politikos ir diplomatinès veiklos formos bei galimybès XIV a. antrojoje pusèje’, Vidurio rytu Europa mūšio prie Mèlynuju vandenu metu. Colloquia Russica, ed. V. Jankauskas, V. Nagirnyy (Kaunas, Kraków, 2013), pp. 189-190.

${ }^{44}$ For example, the case of Mykolas Žygimantaitis. It appears that he was poisoned in Moscow. It is unlikely that Lithuania's lords could have somehow directly contributed to this murder, as Długosz claims. A. Kopystiański, 'Książę 
examples. In his complaint against Jogaila and Skirgaila, Vytautas mentions that after Kęstutis had removed Jogaila from the throne, 'not wanting others to speak ill of him and not wanting to drive anyone from his family away', ${ }^{45}$ he returned Vitebsk to Jogaila, as well as his personal property. A different set of interrelations is evident in the case of Švitrigaila. After his fourth attempt at staging a revolt against the authority of Grand Duke of Lithuania Vytautas, Švitrigaila was ultimatey siezed in 1409. Two unknown dukes from Švitrigaila's circle were beheaded, whilst Švitrigaila himself was imprisoned, being bound in heavy chains (in den ysen gar hertlich halde). The Teutonic Order's grand master heard this news from the komtur of Ragnit, who learnt of it from some unidentified friends arrived from Lithuania. ${ }^{46}$ Later on, Švitrigaila was transferred and imprisoned at Kremenec Castle for nine years until 1418, whereupon he fled to Hungary, assisted by a group of nobles, and reached the Congress of Constance. Two years later, in 1420, with the help of his brother Jogaila and with the assurance of officials from the Kingdom of Poland, Švitrigaila was reconciled with Grand Duke Vytautas. ${ }^{47}$

Attention should also be drawn to the fact that the bond between the grand duke and the ruling family's representatives, and the grand duke and other nobles was not one-sided in terms of loyalty or allegiance. The ruler and those in his inner circle often had to

Michał Zygmuntowicz', Kwartalnik Historyczny, XX (1906), p.163. These doubts are boosted by the fact that following his death, Mykolas was buried in Vilnius Cathedral. S.C. Rowell, 'Išdavyste ar paprasti nesutarimai?', p. 53; Dlugosz senioris canonici Cracoviensis Opera omnia, 14 (liber XII), cura et edita A. Przezdziecki (Cracoviae, 1878), p. 105.

${ }^{45}$ wolde vff sich nich eyn boze wort haben vnd wolde sines geslechtes nimand vortreiben. 'Dis ist Witoldes sache', p. 712.

${ }^{46}$ Letter dated 27 November (1409) from the Ragnit komtur to the Teutonic Order's grand master. Ouch spricht her, das Wytowt herczog Swittirgailn in den ysen gar hertlich halde, und hatte dem herren konynge czu Polau vorschreben, wy her im czu deser czit das vierde vorretnisse wolde haben gethan. Des hät im der konyng czu Polan wedir vorschreben, könne her uff dy worheit komen, das her im thu syn recht, also das deser anders nicht en weis, wen das Wytowt Swyttirgaln habe lassen töten, und hat eygentlich gesehn, das Wytout zwene mechtige herczogen hat lassen köppen, dy sich an Swittirgayln hatten geworfen. The letter is mentioned in $C E V$, no. 434, p. 204. Published in: L. Arbusow, 'Zwölf Urkunden zu O. Stavenhagen: 'Livland und die Schlacht bei Tannenberg', Sitzungsberichte der Gesellschaft für Geschichte und Altertumskunde der Ostseeprovinzen Russlands, aus dem Jahre 1911 (Riga, 1913), no. 1, pp. 265-266.

${ }^{47}$ CEV , no. 889, 890, pp. 489-490. 
manouevre between various interest groups, which if united could definitely pose serious competition to the ruler, or even lead to his overthrow. From Vytautas' complaint against Jogaila and Skirgaila, we discover that Kęstutis and Algirdas decided to overthrow Jaunutis only when they saw 'some injustices done by Duke Jaunutis against them. ${ }^{48}$ The complaint also reveals Vytautas' own motives for opposing his cousin Jogaila. Vytautas claimed that 'Duke Jogaila did not keep his promise, he denied the truth and did not return my patrimony, but gave my patrimony to his brother, Duke Skirgaila.' 49 According to Jan Długosz, the 'father of Polish history', Grand Duke Skirgaila was removed from the throne because he had committed numerous misdeeds against the Lithuanian lords, and because during his reign Catholicism had experienced a steep decline, as the grand duke had relied solely on the opinions of his Orthodox advisers. ${ }^{50}$ It appears that the Lithuanian grand duke Žygimantas Kęstutaitis was killed by nobles for his violent manner. ${ }^{51}$ In the Bychowiec Chronicle, the account of the ruler's murder took on the form of escaping the wrath of a tyron. ${ }^{52}$ On the other hand, as the study by Jarosław Nikodem has revealed, at least Žygimantas Kęstutaitis was no more violent than his contemporaries, such as Švitrigaila, for example. ${ }^{53}$ We learn from Jan Długosz's chronicle that Jonas Čartoriskis (Iwan Czartoryski), one of Žygimantas Kęstutaitis' murderers, received a pardon from the new ruler, Casimir Jagiellon, ${ }^{54}$ whereas Jonas Daugirdas, another of the organisers of this fiendish

${ }^{48}$ jn von herczoge Jawnuten eczliche vnrecht. 'Dis ist Witoldes sache', p. 712.

49 herczog Jagal siner truwe nicht derfollete vnd trata ab siner warheit vnd myn feterlich erbe gab her mir nicht vnd myn feterlich erbe gab her synem bruder herczoger Skirgal. ibid., p. 713.

${ }^{50}$ Jana Dlugosza Roczniki czyli kronika sławnego królestwa Polskiego, (14311444), 11-12, przekład na język polski J. Mrukówna (Warsaw, 2004), pp. 77-78; Further details: A. Lewicki, Powstanie Świdrygietly. Ustęp z dziejów unii Litwy z Korona (Kraków, 1892), pp. 146-149.

${ }^{51}$ S.C. Rowell, 'Bears and Traitors', pp. 30-31, 45-55.

52 The chronicler put these words into the mouth of Prince Iwan Czartoryszki, the main conspirator in Žygimantas Kęstutaitis' murder, perhaps as a sort of justification: Szto iesi byt nahotowat kniazem y panom y wsim nam pity, toie ty teper piy odyn. 'Хроника Быховца', Полное собрание русских летописей, 32, сост. и ред. Н. Н. Улащик, (Москва, 1975), р. 156.

53 J. Nikodem, 'Przyczyny zamordowania Zygmunta Kiejstutowicza', Białoruskie Zeszyty Historyczne, 17 (2002). http://kamunikat.fontel.net/www/czasopisy/ bzh/17/17art_nikodem.htm (accessed on 10-01-2013).

${ }^{54}$ Jana Dlugosza Roczniki, pp. 283-285. 
plot, kept his post as the Palatine of Vilnius. ${ }^{55}$ It appears that the results for the organisers of this plot were not so bad. The only one to lose his post was Petras Leliušas, the Palatine of Trakai. ${ }^{56}$

\section{The emergence of the concept of treason against the Grand Duke of Lithuania}

By analysing the different content in the peace treaties of 1435 between Ilya, the Palatine of Moldova, and Žygimantas Kęstutaitis, the Grand Duke of Lithuania, ${ }^{57}$ of 1442 between the same Palatine of Moldova and Casimir, the Grand Duke of Lithuania, and the treaty of 1447 between the Palatine of Moldova Stefan and Casimir, the Grand Duke of Lithuania, ${ }^{58}$ we can observe a qualitative change to the foe category in the legal discourse. In the treaty of 1435 , both sides promised not to support one another's enemies, 'and to be foes to each other's enemies'. ${ }^{59}$ By 12 years later, in the treaty of 1442 between Casimir, the Grand Duke of Lithuania, and the same Ilya, Palatine of Moldova, this norm was expanded considerably. The following norm was added to their agreement regarding common enemies:

our Ilya, the palatine, shall not keep any foe of ours in his domains, and we too shall not keep any foe of Ilya, the palatine, in our domains. And whomsoever desires to harm our lives, and flees to the domains of Ilya, the palatine, then he must extradite such traitors from his domains to us. And whomsoever desires to do such harm to Ilya, the palatine, and flees to our domains, we too must extradite this traitor from our domains and hand him over to Ilya, the palatine. ${ }^{60}$

${ }^{55}$ R. Petrauskas, Lietuvos diduomene, pp. 224-225.

${ }^{56}$ For more on the murder of Žygimantas Kęstutaitis and its outcomes: R. Petrauskas, Lietuvos diduomene, pp. 182-185.

${ }^{57}$ Original document: AGAD, Zbiór dokumentów pergaminowych, 7285. The wrong year of 1437 features on the treaty act entered into the books of the Lithuanian Metrica. The error must have been made when the book was being rewritten. $L M 5$, no. 538, p. 354-355. For more about the dating of the treaty: I. Czamańska, Mołdawia $i$ Woloszczyzna wobec Polski, Wegier i Turcji w XIV $i$ XV wieku (Poznań, 1996), p. 99, footnote 306. Also, M. Costăchescu, Documentele moldoveneşti înainte de Ştefan cel Mare, II (Iaşi, 1933), pp. 691-692.

${ }^{58}$ Ilona Czamańska dates this treaty to 1442: I. Czamańska, Mołdawia, p. 100, footnote 309; Mihaius Costăchescu's publication gives the year 1445: M. Costăchescu, Documentele, pp. 725-728.

${ }^{59}$ а непрыятелемъ его непрыятелемъ быти. LM 5, по. 538, р. 355.

${ }^{60}$ А непрыятеля нашого Ильи, воеводе, противъ насъ у его земли не держати, а намъ такожь неприятеля Ильи, воеводы, у нашои земли против его не деръжати. А хто пожедаеть, погадаеть на нашь жывоть, а збежыть 
This form of expression was repeated in the treaty of 1447 between Casimir, the Grand Duke of Lithuania, and Stefan, the Palatine of Moldova. ${ }^{61}$ Acts of treason against the ruler were also mentioned in the privilege of Grand Duke Casimir to the nobility in $1447 .{ }^{62}$ On the one hand, changes to inter-state treaty norms would have been related to specific political circumstances, but on the other hand, the use of the term traitor (зрадиа) in this context would suggest that it became necessary to distinguish between the categories of foes and traitors.

The identification of the traitor or traitors in the treaties mentioned is quite difficult, as we do not have any sources that can identify these figures specifically. It could be that we shall have to agree with the opinion of Adrian Kopystiański, who thinks that it was Mykolas Žygimantaitis who was referred to in the treaties, Grand Duke Casimir's contender for the Vilnius throne. ${ }^{63}$ Note that in the 1440 s and 1450s, according to Jan Długosz, seven unsuccessful attempts were made on the life of Casimir Jagiellon. ${ }^{64}$ Perhaps the text dated 29 March 1523 from the legation from Sigismund the Old, the Grand Duke of Lithuania, to Stefan, the Palatine of Moldova, regarding Sharpa, the palatine's fugitive council member, the author recalled the grand duke's subordinates who were associated with one of the failed attempts on the life of Grand Duke Casimir. In the legation's text, Grand Duke Sigismund stated:

some subjects of His Grace [Casimir], also fearing their lord's wrath, fled to your grandfather the palatine Stefan, and your grandfather asked our father King Casimir, and in response to your grandfather's request, our father King Casimir spared them his wrath, and immediately accepted them back, returning to them their honour, domains and treasuries. ${ }^{65}$

въ Ильи, воеводину, земълю, того издрадъиу Илья, воевода, маеть намъ зъ его земли выдати. А хто Или, воеводинъ, жывоть погадаеть, а забежыть у наму землю, и мы имаем також того зъдрадиу з намее земли Ильи, воеводи, выдати. LM 5, nо. 539, p. 355. The Moldovan side's treaty has a slightly different text. ibid., no. 544 , p. 361 .

${ }^{61}$ А хто погадаеть на князя великого жывоть и забежыть в нашу землю, и мы имаемъ того зърадияа выдати з нашое земли князю великому. А хто иметь погадат на нашъ жывоть и забежыт у князя великого землю, и князь великии Казимир мает намъ того намого зърадиу выдати. ibid., no. 543, p. 360.

${ }^{62}$ Kodex dyplomatyczny polski, 1, wyd. L. Rzyszczewski, A. Muczkowski, A. Z. Helcel (Warsaw, 1847), no. 188, p. 335.

${ }^{63}$ A. Kopystiański, 'Książę Michał...', pp. 116, 123-124, 133.

${ }^{64}$ Długosz mentions this twice. Joannis Dlugosz senioris, pp. 29, 139.

${ }^{65}$ некоторыи подъданыи его м(и)л(о)сти [Казимера] такимъ же обычаемъ напудивши ся гневу втекли до дида твоего Стефана, воеводы, и дидъ твои 
Perhaps the subject in question here is Duke Mykolas Žygimantaitis, who had then fled to Moldova. ${ }^{66}$ Grand Duke Casimir issued an 'iron' security writ on 1 July 1447, allowing Duke Mykolas Žygimantaitis to freely arrive in Krakow. ${ }^{67}$ The researcher knows of two specific cases of attempts on the life of Grand Duke Casimir. The culprit was identified in sources in only one of these cases. Jan Długosz mentions that in 1446, a lord from Volozhin (the prince?) threatened the ruler, possibly Grand Duke Casimir's chamber servant, Suchta. ${ }^{68}$ The extensive digest of Lithuania's chronicles also makes reference to Suchta's threat, mentioning that five brothers, princes of Volozhin, were sentenced to death for their deeds. ${ }^{69}$ Reflections of this event can also be found in Grand Duke Casimir's judicial book (a record of privileges he granted to the nobility). It contains an undated entry outlining that Casimir had granted Volozhin to a lord, Ivashka Mangirdaitis. ${ }^{70}$ Eugenijus Saviščevas, who has researched Casimir's book of privileges, has compiled a register of likely acts, and presents the possible granting dates. According to Saviščevas, Volozhin was indeed granted to Ivashka Mangirdaitis (1440-1447). ${ }^{71}$ Following the unsuccessful threat on Grand Duke Casimir's life in late 1446, some of the conspirators were sentenced to death, and their property was seized and transferred to the ruler's treasury, part of which (Volozhin) was granted to Ivashka Mangirdaitis. It was suspected that one of the conspirators could have been Duke

отиа нашого Казимера, короля, за таковыми прошиваль, и отеи нашъ Казимер, король, на прозбу дида твоего гнев свои имъ отпускиваль и зася в ласку свою их приимоваль, и при чтяхъ, именьяхъ и скарбехъ их заставъляль. Lietuvos Metrika (1506-1539), 7-oji Užrašymu knyga, compiled by I. Ilarienè, L. Karalius, D. Antanavičius (Vilnius, 2011), no. 229, p. 421.

${ }^{66}$ A. Kopystiański, 'Książę Michał...' pp. 133-134.

${ }^{67}$ Codex epistolaris saeculi decimi quinti, 3 (1392-1501). Monumenta medii aevi historica res gestas Poloniae illustrantia, collectus opera A. Lewicki (Cracoviae, 1894), no. 11, pp. 18-19.

${ }^{68}$ Szuchta Rutenici generis et ritus Dux. Joannis Dlugosz senioris, p. 29; for more details: S.C. Rowell, 'Išdavystė ar paprasti nesutarimai?', pp. 53-54, footnote 32; idem, 'Bears and Traitors', p. 37, footnote 44.

${ }^{69}$ Хроника Быховиа, р. 159.

${ }^{70}$ Lietuvos Metrika (1440-1498), 3-oji Užrašymu knyga (henceforth LM 3), compiled by L. Anužytè, A. Baliulis (Vilnius, 1998), p. 20.

${ }^{71}$ E. Saviščevas, 'Suvaldyti chaosą: bandymas naujai tirti Lietuvos didžiojo kunigaikščio Kazimiero suteikčių knygą', Istorijos šaltiniu tyrimai, 1, compiled by D. Antanavičius, D. Baronas (Vilnius, 2008), p. 142, 29 SA. 
Mykolas Žygimantaitis. ${ }^{72}$ Perhaps, fearing the 'wrath' of his ruler, Duke Mykolas Žygimantaitis fled Lithuania. Our knowledge of another threat that was to occur in the first half of 1453 comes to us from the announcement of the Torun komtur's and Teutonic Order's spy to the grand master of the Order, dated 17 May. ${ }^{73}$ According to the grand master's informants, following the threat on his life, Grand Duke Casimir spent ten weeks recovering, isolated from the nobility. Although we have no data, we can presume that the fugitive Medininkai tivun Ignotas might have been involved in the attempt on Casimir's life. The tivun's lands were granted to Hlebas Andrejevičius on 15 March 1453. ${ }^{74}$

\section{In summary}

The demand for the codification of acts of treason against the ruler as a crime emerged in the milieu of Casimir, the Grand Duke of Lithuania, recorded in inter-state treaties with Moldova and in Casimir's privilege to the nobility of 1447 . As was already mentioned, this impulse must have been related to several circumstances. At first glance, it would appear that it was associated with threats made on Casimir's life. On the other hand, as we saw, this practice was rather widespread earlier as well, in the 1430 s and the mid-15th century. That is why, within the framework of custom law, treason could have been treated as a crime much earlier, even during Lithuania's pagan era. Why did it not emerge then? Probably the main reason why treason as a crime did not function in Lithuania until the beginning of the 14th century was that prior to the 'early modernisation' period, Vytautas' era, there were state structures based on archaic bonds. The cancellation of these bonds, or going beyond the boundaries of loyalty and allegiance were not comprehended as a crime, but as a demonstration of hostility. Therefore, such individuals or groups of individuals were attributed to the category of adversary or foe, and the semantic field for this terminology practically corresponded with

72 At least that is the information presented in the comprehensive digest of Lithuanian chronicles Хроника Быховиа, p. 159.

${ }^{73}$ S.C. Rowell, Appendix, 'Išdavystè ar paprasti nesutarimai?', no. 4, 5, pp. 67-70.

74 The privilege was issued in the name of Goštautas, the Palatine of Vilnius. Глебу Андреевичу Игнатъкова земля подъ тивуна медниикого, занюж тот деи Игнатко збегль своего места. Април(я) 15, инъдикть 1. Панъ Кгастовтъ, воевода виленскии. LM 3, p. 22; E. Saviščevas, 'Suvaldyti chaosą', pp. 142, 58 SA. 
the enemy category. The emergence of terms for treason is evidence of an intensification of links between state structures, where close ties were established between the ruler and his officials/friends, primarily within the institutional environment of the ruler's court, and the public offices. An increasing number of nobles were drawn into the mechanism of state structures, who were considered and held themselves to be members of the ruling and state body. It was precisely in this case that stepping over the boundaries of loyalty and allegiance was treated as the crime of treason.

\section{Author Details}

Andrej Ryčkov is engaged in a joint doctoral programme at the Lithuanian Institute of History and Vilnius University. The theme of his dissertation is 'The Concept of Treason against the Grand Duke of Lithuania from the End of the 13th Century to the mid-16th Century'.

Address: Lithuanian Institute of History, Kražių g. 5, Vilnius LT-01108

E-mail: andrej.ryckov@gmail.com

\section{References}

ALTHOFF, G. Verwandte, Freunde und Getreue. Zum politischen Stellenwert der Gruppenbindungen im früheren Mittelalter (Darmstadt, 1990).

ARBUSOW, L. 'Zwölf Urkunden zu O. Stavenhagen: 'Livland und die Schlacht bei Tannenberg", in Sitzungsberichte der Gesellschaft für Geschichte und Altertumskunde der Ostseeprovinzen Russlands, aus dem Jahre 1911 (Riga, 1913).

BACKUS, O. 'Treason as a Concept and Defections from Moscow to Lithuania in the Sixteenth Century', in Forschungen zur Osteuropäischen Geschichte, 15(1970).

Lietuvos istorija. T. 3: BARONAS, D., DUBONIS, A., PETRAUSKAS, R. XIII a.-1385 m.: valstybès iškilimas tarp Rytu ir Vakaru (Vilnius, 2011).

BILLORÉ, M., SORIA, M. (eds.), La trahison au Moyen Âge: de la monstruosité au crime politique, Ve-XVe siècle (Rennes, 2009).

Codex epistolaris saeculi decimi quinti, 3 (1392-1501). A. Lewicki (collect.). Cracoviae: Wydawnictwa Komisyi Historycznej Akademii Umiejętności w Krakowie (1894).

Codex epistolaris Vitoldi magni ducis Lithuaniae 1376-1430. A. Prochaska (collect.). Cracoviae: Wydawnictwa Komisyi Historycznej Akademii Umiejętności w Krakowie (1882). 
COSTĂCHESCU, M. (ed.), Documentele moldoveneşti înainte de Ştefan cel Mare, 2 (Iaşi, 1933).

CUTTLER, S.H. The Law of Treason and the Treason Trials in the Later Medieval France (Cambridge, et al., 2003).

CZAMAŃSKA, I. Mołdawia i Wołoszczyzna wobec Polski, Wegier $i$ Turcji w XIV i XV wieku (Poznań, 1996).

ČAPAITĖ, R. 'Lietuvos didžiojo kunigaikščio Vytauto kasdienybè pagal jo ir jo amžininkų korespondenciją’, in Alytaus miesto istorijos fragmentai, A. Jakunskienè (ed.) (Alytus, 2001).

Die Staatsverträge des Deutschen Ordens in Preußen im 15. Jahrhundert. Bd. 1. (1398-1437). E. WEISE (Hrsg.) (Königsberg, 1939).

DYJAKOWSKA, M. Crimen laesae maiestatis. Studium nad wptywami prawa rzymskiego $w$ dawnej Polsce (Lublin, 2010).

DUBONIS, A. 'Raštininkas', in Lietuvos Didžiosios Kunigaikštijos kultūra.Tyrinẹjimai ir vaizdai, eds. V. Ališauskas, L. Jovaiša, M. Paknys, R. Petrauskas, E. Raila (Vilnius, 2001).

DUBONIS, A. 'Žemèvalda', in Lietuvos Didžiosios Kunigaikštijos kultūra. Tyrinejimai ir vaizdai, eds. V. Ališauskas, L. Jovaiša, M. Paknys, R. Petrauskas, E. Raila (Vilnius, 2001).

Jana Długosza Roczniki czyli kronika sławnego królestwa Polskiego. (1431-1444). 11-12. Przekład na język polski J. Mrukówna (Warsaw, 2004).

Joannis Dtugosz senioris canonici Cracoviensis Opera omnia, 14 (liber XII). A. PRZEZDZIECKI (cur. and ed.). (Cracoviae, 1878).

Kodex dyplamatyczny polski, 1, L. Rzyszczewski, A. Muczkoeski, A. Z. Helcel (wyd.) (Warsaw, 1847).

KOPYSTIAŃSKI, A. 'Książę Michał Zygmuntowicz', in Kwartalnik Historyczny, 20 (1906).

KORANYI, K. 'O niektórych postanowieniach karnych Statutu litewskiego z r. 1529 (Studium prawno-porównawcze)', in ed. S. Eherenkreutz Księga pomiantkowa ku uczczeniu czterechsetnej rocznicy wydania pierwszego Statutu Litewskiego, (Wilno, 1935).

KORCZAK, L. Litewska rada wielkoksiązęca w XV wieku (Kraków, 1998).

KORCZAK, L. Monarcha i poddani. System władzy w Wielkim Księstwie Litewskim w okresie wczesno jagiellońskim (Kraków, 2008).

KOTZEBUE, A. Switrigail. Ein Beytrag zu den Geschichten von Litthauen, Rusland, Polen und Preussen (Leipzig, 1820).

LEWICKI, A. Powstanie Świdrygietly. Ustęp z dziejów unii Litwy z Korona (Kraków, 1892).

Lietuvos Metrika (1387-1546), 25-oji Užrašymu knyga. Compiled by

D. Antanavičius, A. Baliulis (Vilnius, 1998).

Lietuvos Metrika (1427-1506), 5-oji Užrašymu knyga. Compiled by

A. Baliulis, A. Dubonis, D. Antanavičius (Vilnius, 2012). 
Lietuvos Metrika (1506-1539), 7-oji Užrašymu knyga. Compiled by I. Ilarienè, L. Karalius, D. Antanavičius (Vilnius, 2011).

LITYŃSKI, A. Przestępstwa polityczne $w$ polskim prawie karnym XVI-XVIII wieku (Katowice, 1976).

Liv-, esth- und curländisches Urkendenbuch, Bd. 4. F. G. von BUNGE (Hrsg.) (Reval, 1859).

NIKODEM, J. 'Przyczyny zamordowania Zygmunta Kiejstutowicza', in Białoruskie Zeszyty Historyczne, 17 (2002).

NORKUS, Z. Nepasiskelbusioji imperija. Lietuvos Didžioji Kunigaikštija lyginamosios istorinès imperiju sociologijos požiūriu (Vilnius, 2009).

PETRAUSKAS, R. 'Ankstyvosios valstybinès struktūros Lietuvoje XIII amžiuje-XV amžiaus pradžioje', in Lietuvos istorijos studijos, 16 (2005).

PETRAUSKAS, R. 'Didžiojo kunigaikščio institucinio dvaro susiformavimas Lietuvoje (XIV a. pabaigoje - XV a. viduryje)', in Lietuvos istorijos metraštis. 2005/1 (2006).

PETRAUSKAS, R. 'Gediminaičių pasaulis: tarptautinès politikos ir diplomatinès veiklos formos bei galimybès XIV a. antrojoje pusèje', Vidurio rytų Europa mūšio prie Mèlynujų vandenu metu, eds. V. Jankauskas, V. Nagirnyy (Kaunas, Kraków, 2013).

PETRAUSKAS, R. 'Giminaičiai ir pavaldiniai: Lietuvos bajorų grupès XIV a. pabaigoje-XV a. I pusejje', in Lietuva ir jos kaimynai. Nuo normanu iki Napoleono: prof. B. Dundulio atminimui, ed. I. Valikonytė (Vilnius, 2001).

PETRAUSKAS, R. Lietuvos diduomenè XIV a. pabaigoje - XV a.: sudètis - struktūra - valdžia (Vilnius, 2003).

PETRAUSKAS, R. 'Nuo Vytauto iki Aleksandro Jogailaičio: didžiojo Lietuvos kunigaikščio dvaro tęstinumo problema', in Lietuvos didysis kunigaikštis Aleksandras ir jo epocha, ed. D. Steponavičienė (Vilnius, 2007).

RYČKOV, A. 'Valdovo išdavystès kaip nusikaltimo sampratos ištakos Lietuvoje', in Lietuvos istorijos metraštis. 2013 metai 2 (2014).

ROWELL, S.C. 'Bears and Traitors, or: Political Tensions in the Grand Duchy, ca. 1440-1481', in Lithuanian Historical Studies 2 (1997).

ROWELL, S.C. (ed.) Chartularium Lithuaniae res gestas magni ducis Gedeminne illustrans (Vilnius, 2003).

ROWELL, S.C. 'Išdavystè ar paprasti nesutarimai? Kazimieras Jogailaitis ir Lietuvos diduomenè 1440-1481 metais', in Lietuvos valstybe XII-XVIII a., Z. Kiaupa, J. Sarcevičienè et al. (Vilnius, 1997).

RUSTEMEYER, A. 'Princes, parents et seigneurs. Loyautés et crime contre le souverain en Europe centrale ou occidentale et en Moscovie XIVe - XVIIe siècle', in Cahiers du monde russe 46 (2005).

SAVIŠČEVAS, E. 'Suvaldyti chaosą: bandymas naujai tirti Lietuvos didžiojo kunigaikščio Kazimiero suteikčių knygą’, in Istorijos šaltiniu tyrimai 1 (2008). 
SCHER, S. 'Sociologie de la trahison', in Cahiers Internationaux de Sociologie 123/2 (2007).

Scriptores rerum prussicarum. Bd. 2. Th. Hirsch, M. Töppen und E. Strehlke (Hrsg.) (Leipzig, 1863).

VALIKONYTĖ, I., LAZUTKA, S., GUDAVIČIUS, E. Pirmasis Lietuvos Statutas (1529 m.) (Vilnius, 2001).

VOLUNGEVIČIUS, V. Pilies šešélyje. Teritorija, visuomenè ir valdžia Lietuvos Didžiojoje Kunigaikštystèje (Vilnius, 2015).

БЕНВЕНИСТ, Э. Словарь индоевропейских социальных терминов. I. Хозяйство, семья, общество. ІІ. Власть, право, религия, перевод с французкого Н.Н. Казанского, Б.П. Нарумова, С.Г. Проскурина, О.М. Савелевой, Н.Л. Сухачева, (Москва, 1995).

БЛАНУЦА, А., ВАЩУК, Д. 'Інститут «старини» й «новини» в правах та економічних джерелах Великого князівства Литовського (друга половина XV-XVI ст.)', in Украӥнський історичний журнал, 467/2 (2006).

ВАЩУК, Д. 'Абыхмо деръжали ихъ пФдль права ихъ земъли' (Населення Київщини та Волині ї великокнязївська влада в XV-XV cm.) (Київ, 2009).

'Вірність' - 'зрада' в уявленнях і практиках середньовіччя і раннього нового часу. Соиіум. альманах соичальної історії. (Київ, 2006).

Гістарычны слоўнік беларускай мовы, 4. Р.С. Гамзовіч ... et al. (сост.) (Мінск, 1984).

Гістарычны слоўнік беларускай мовы, 20. А.М. Булыка ... et al. (сост.) (Мінск, 2001).

Грамоти XIV cm. Памятки украіньскоі мови. Упорядкування, вступна стаття, коментарі і словники-покажчики М. Пещак. (Киів, 1974).

ГРУША, А. 'Улада непарушнасці і памяці: 'старина' і яе трансфармацыя ў XV - першай трэці XVI ст.', in Соціумм. Альманах соиіальної icmopiï 10 (2013).

ЕРУСАЛИМСКИЙ, К. 'Рождение государственной измены: Россия и Польско-Литовское государство конца XV-XVI вв.', in Одиссей. Человек в истории. Предательство: опьт исторического анализа (Москва, 2012).

ЛАЗУТКА, С., ВАЛИКОНИТЕ, И., ГУДАВИЧУС Э. Первый Литовский Статут (1529 г.) (Вильнюс, 2004).

ЛЕВИНСОН, К. 'Предисловие', in Одиссей. Человек в истории. Предательство: опыт исторического анализа (Москва, 2012).

КРОМ, М. '«Старина» как категория средневекового менталитета (по материалам Великого княжества Литовского XIV - начала XVII вв.)', in Mediaevalia исrainica. Ментальність та історія ідей 3 (1994).

Полное собрание русских летописей, 32. Н. Улащик (сост. и ред.) (Москва, 1975).

Полное собрание Русских летописей, 35. Н. Улащик (сост. и ред.) (Москва, 1980). 
Полочкие грамоты. ХІІІ - начала XVI вв., А. Л. Хорошкевич (сост.) (Москва, 1977).

Україньскі грамоти, (XIV в. і перша половина XV в.), А. В. Розов (выд.) (Київ, 1928).

ХОРОШКЕВИЧ, А. '«Здрада» Статута Великого княжества Литовского 1588 г., «измена» Соборного Уложения 1649 г. и демографическая политика восточноевропейских государвств конца XVI - начала XVII вв.', in 1588 metu Trečiasis Lietuvos Statutas, Respublikinès mokslinès konferencijos, skirtos Trečiojo Statuto 400 metinèms pažymèti, medžiaga (Vilnius, 1989). 


\section{VIDINIAI VALDOVO IŠDAVYSTĖS KAIP NUSIKALTIMO \\ SAMPRATOS ATSIRADIMO VEIKSNIAI LIETUVOS DIDŽIOJOJE KUNIGAIKŠTYSTÉJE XIV A. VIDURYJE-XV A. VIDURYJE}

Santrauka

ANDREJ RYČKOV

Straipsnyje analizuojami vidiniai valdovo išdavystės kaip nusikaltimo sampratos atsiradimo LDK veiksniai XIV a. vid. - XV a. vid. Apibendrinant istoriografiją, kuri nagrinėjo valdovo išdavystès problemą LDK, galime konstatuoti, kad išdavyste visų pirma buvo tirta remiantis XVI a. šaltiniais, o to laikotarpio išdavystės samprata taikoma ir ankstesnèms epochoms. Būtų klaidinga manyti, kad valdovo išdavystès kaip nusikaltimo samprata XV a. pirmoje pusejje buvo tapati jos sampratai po 100 metų - XVI a. pirmoje puseje. Šiuo laikotarpiu įvyko ne tik milžiniškas visuomenès socialinių struktūrų pokytis, bet ir valstybès struktūrų transformacija. Archajiškais asmeniniais ryšiais paremtą valstybès valdymą keite institucinis valstybès valdymo modelis. Tyrimas parodè, kad pagrindinè socialinè grupé, kurioje èmé formuotis šis nusikaltimas XV a. pr. - XV a. vid., buvo didžiojo kunigaikščio varžovai ir nedraugai (lot. adversarius, inimicus; rusèn. недруг, неприятель, враг; vok. fynd). Išdavystès terminų atsiradimas būtent šioje socialinèje grupèje liudija apie valstybinių struktūrų ryšio intensyvėjimą, kai tarp valdovo ir jo pareigūnų / draugų užsimezga glaudūs ryšiai. Visų pirma tai vyksta valdovo institucinio dvaro terpèje bei per pareigybių sistemą. Būtent šiuo atveju ištikimybès ir lojalumo ribos peržengimas buvo imtas suvokti jau nebe kaip priešiškumas, o kaip išdavystès nusikaltimas. 